\title{
Recombinant Human Enkephalinase (Neutral Endopeptidase) Prevents Cough Induced by Tachykinins in Awake Guinea Pigs
}

\author{
H. Kohrogi, J. A. Nadel, "*\$ B. Malfroy," C. Gorman," R. Bridenbaugh," J. S. Patton," and D. B. Borson"* \\ *Cardiovascular Research Institute and the Departments of ${ }^{\ddagger}$ Physiology and ${ }^{\S}$ Medicine, University of California, \\ San Francisco, San Francisco, California 94143; and "Genentech, Inc., South San Francisco, California, 94080
}

\begin{abstract}
To determine whether recombinant enkephalinase (neutral endopeptidase, EC 3.4.24.11) prevents cough induced by exogenously applied and endogenously released neuropeptides, we measured cough responses to aerosolized solutions of substance $P$ or of capsaicin for 2 min in random-source guinea pigs before or after exposing them to aerosolized recombinant human enkephalinase. Substance $P\left(10^{-16} \mathrm{M}\right)$ increased coughing compared with its vehicle. Enkephalinase (120 $\mu \mathrm{g})$ inhibited cough induced by subsequent exposure to substance $P$ compared with the response to substance $P$ alone, but after further exposure to the enkephalinase inhibitor leucine-thiorphan $\left(10^{-5} \mathrm{M}\right)$, substance $P$ increased cough significantly. Similar results were obtained for capsaicin-induced cough. In pathogen-free guinea pigs, after they inhaled inactive recombinant enkephalinase $(33 \mu \mathrm{g})$, capsaicin $\left(10^{-13} \mathrm{M}\right)$ increased cough significantly. In contrast, after they inhaled active recombinant enkephalinase ( $33 \mu \mathrm{g})$, capsaicin increased cough only slightly. These results suggest that aerosolized enkephalinase reaches the sites of release or actions of endogenous neuropeptides and, by degrading them, prevents cough induced by their release. Furthermore, these studies suggest that recombinant enkephalinase might be useful in the treatment of cough and other symptoms of diseases involving peptides cleaved by this enzyme.
\end{abstract}

\section{Introduction}

Cough is an important respiratory defense mechanism $(1,2)$ that promotes clearance of material from the airways. However, prolonged, uncontrolled, or nonproductive cough is one of the most important symptoms of respiratory disease. Although sensory nerve endings are believed to transmit impulses to the central nervous system via the vagus nerves (3-5), the biochemical mechanisms of cough are not known.

There is evidence that endogenous neuropeptides such as substance $P$ and other tachykinins may modulate airway function. Substance $P$ is present in sensory nerves in the air-

Dr. Kohrogi's present address is the First Department of Internal Medicine, Kumamoto University Medical School, 1-1-1 Honjo, Kumamoto 860, Japan.

Address reprint requests to Dr. Jay A. Nadel, Cardiovascular Research Institute, Box 0130, University of California, San Francisco, San Francisco, CA 94143-0130.

Received for publication 25 January 1989 and in revised form 11 April 1989.

J. Clin. Invest.

(c) The American Society for Clinical Investigation, Inc. 0021-9738/89/09/0781/06 \$2.00

Volume 84, September 1989, 781-786 ways of several species (6), including humans (7). Substance $P$ stimulates many airway responses including gland secretion $(8$, $9)$, smooth muscle contraction $(10,11)$, increased vascular permeability (12), and neutrophil adhesion to the venous endothelium (13), and it potentiates cholinergic neurotransmission $(11,14)$. We have recently shown that inhibitors of enkephalinase (neutral endopeptidase, EC 3.4.24.11) potentiate the effects of substance $P$ on secretion of macromolecules from submucosal glands (9), on smooth muscle contraction $(11,15)$, on cholinergic neurotransmission (11), on vascular permeability $(16,17)$, on neutrophil adhesion (18), and on chemotaxis (19). These results suggest that the effects of tachykinins and other peptides are modulated by endogenous enkephalinase that is present in airway epithelium, smooth muscle, nerves, and submucosa (20).

We have also shown that substance $P$ stimulates cough responses in awake guinea pigs (21). Capsaicin, which releases neuropeptides such as substance $P$ and other tachykinins from sensory nerves (22-24), stimulates cough responses in humans (25) and in guinea pigs (26). Furthermore, we found that enkephalinase inhibitors potentiate cough responses induced by low concentrations of substance $P$ and by capsaicin (21), most likely by inhibiting the enkephalinase known to be present in the guinea pig airways (27).

From these results, we reasoned that exogenously applied enkephalinase might decrease or prevent cough initiated by these peptides if it had access to the sites of release of the peptides or to the receptors that mediate cough. The recent cloning of human enkephalinase (28) now provides the opportunity to study the potential therapeutic uses of recombinant human enkephalinase. Because cough is such a prominent and poorly treated feature of pulmonary diseases, we chose to study the effects of recombinant human enkephalinase on substance P- and capsaicin-induced cough in awake guinea pigs.

\section{Methods}

Measurement of cough responses. Cough responses in 33 guinea pigs (male Hartley, weighing 450-550 g) were measured as previously described (21). Animals were treated according to approved procedures of the Committee on Animal Care at the University of California, San Francisco. Each animal was placed in a 1-liter glass jar and allowed to relax. Two 5-mm-diam holes were made in the cap of the jar. One was connected to a source of constant airflow of 0.6 liters $/ \mathrm{min}$ and provided fresh air to the inside of the jar. Aerosols were generated at 0.2 $\mathrm{ml} / \mathrm{min}$ by an ultrasonic nebulizer (model 25; DeVilbiss Co., Somerset, PA), which produces particles with a mean mass diameter of 7.6 $\pm 2.6 \mu \mathrm{m}$ (geometric standard deviation). The other hole was connected to a pneumotachograph (Model 00; Fleisch, Richmond, VA), which was attached to a differential strain gauge (Model PM5 Statham-Gould, Inc., Hato Rey, PR), and airflow was recorded on a polygraph (Model 5D; Grass Instruments Co., Quincy, MA). Addi- 
tionally, cough is associated with a characteristic motion of the animal that can be observed visually. Cough was detected as transient changes in airflow (a rapid inspiration followed by a rapid expiration). Because other motions of the guinea pig in the jar also can produce changes in airflow, the activity of the animals was monitored continuously and motion-induced changes in airflow were disregarded. Thus, we counted as coughs only those events that could be confirmed by both visual observation and by the airflow record.

Preparation of recombinant human enkephalinase. Recombinant enkephalinase was produced in 293 cells, a transformed cell line derived from the kidney (29), according to methods previously published (30) and was purified intact from the cell membranes using modifications of existing methods (31). These methods include solubilization of the enzyme in detergent, followed by chromatography using columns of Con A, DEAE Sephacel (Pharmacia Fine Chemicals, Piscataway, $\mathrm{NJ}$ ), and hydroxyapatite. Enzymatic activity was measured under initial velocity conditions using published methods ( 31$)$ and expressed in micrograms total aerosolized dose, where $1 \mathrm{ng}$ of recombinant enkephalinase degrades $20 \%$ of a solution ( $20 \mathrm{nM}$ or less) of [ $\left.{ }^{3} \mathrm{H}-\mathrm{Tyr}, \mathrm{D}-\mathrm{Ala}^{2}\right]-$ leucine enkephalin at $20^{\circ} \mathrm{C}$ in $30 \mathrm{~min}$, and it degrades $40 \%$ of the substrate at $37^{\circ} \mathrm{C}(0.1 \mathrm{ng}$ degrades 2 and $4 \%$, respectively).

Because enkephalinase is normally an integral part of cell membranes including those of 293 cells, its purification requires the use of detergents (31). Preliminary experiments demonstrated that the detergents used in its purification (Triton X-100 and Tween 80) caused cough by themselves. Therefore, we developed a preparation of enkephalinase incorporated into liposomes that was devoid of excess detergents. The lipids (Avanti Polar Lipids, Birmingham, AL) were prepared using $25 \mathrm{mg}$ egg phosphatidylcholine (molecular weight $=786$ ), $10.6 \mathrm{mg}$ dioleoylphosphatidylglycerol (molecular weight $=774$ ), and $8 \mathrm{mg}$ cholesterol (molecular weight $=387$ ), which were mixed (molar ratio, 4.5:2:3), dried under nitrogen, redissolved in hexane, and redried. $3 \mathrm{ml}$ of Hepes-buffered saline $(50 \mathrm{mM}, 125 \mathrm{mM}$ $\mathrm{NaCl}$ ) were added to the lipid mixture, which was then vortexed at high speed for $2 \mathrm{~min}$. This mixture was then pressed three times through two filters (Nuclepore Corp., Pleasanton, CA) with $50 \mathrm{~nm}$ diameter exclusion size using a liposome extruder press (The Extruder; Lipex Biomembranes, Inc., Vancouver, BC; $250 \mathrm{lb} \cdot$ in $^{-2}$ ). Enkephalinasecontaining liposomes were made by mixing Triton X-100, liposomes, and enkephalinase together at a ratio of detergent/lipid/protein of 5.6:1.4:1, respectively, vortexing the mixture for $2 \mathrm{~min}$, and then dialyzing the preparation exhaustively against Hepes-buffered saline in tubing (no. 2; Spectropore, Los Angeles, CA) that allows molecules of $12,000-14,000 \mathrm{D}$ to pass through. The dialysis buffer (1 liter) was changed daily, and after $5 \mathrm{~d}$ the dialysis reached equilibrium. Studies using radiolabeled Triton X-100 showed that $99 \%$ of the detergent was removed by $5 \mathrm{~d}$ of dialysis and that the remaining radioactivity $(\sim 1 \%)$ was not lost, even with further dialysis. The enzymatic activity of the recombinant enkephalinase was not altered by its incorporation into liposomes, and leucine-thiorphan inhibited activity $\left(K_{\mathrm{I}}=\sim 10^{-9} \mathrm{M}\right)$. These results suggest that the active sites of the enzyme molecules were on the outside of the liposome and were thus able to cleave peptide substrates.

The enkephalinase-liposome preparation caused cough in several of the guinea pigs studied, an effect probably due either to the residual detergent present or to the lipids in the liposomes. Therefore, we made a preparation of enkephalinase in the absence of liposomes by dialyzing exhaustively ( 1 liter each for five changes) purified, recombinant enzyme against Hepes-buffered saline. Dialysis for $5 \mathrm{~d}$ did not alter the enzymatic activity of the preparation, and the solution remained optically clear; no precipitate formed. Subsequent studies demonstrated that this preparation did not cause cough by itself.

Substance $P$ - and capsaicin-induced cough. In the first series of experiments, to determine whether recombinant enkephalinase inhibits cough induced by substance $P$, we exposed five healthy, random-source guinea pigs to aerosols first of saline $(2 \mathrm{~min}$ ) followed by 8 min of additional observation, during which time coughs were counted. The animals were then exposed to aerosolized substance $P$ $\left(10^{-16} \mathrm{M}, 2 \mathrm{~min}\right.$ ), and coughs were monitored for an additional $8 \mathrm{~min}$. The concentration of substance $P$ was chosen on the basis of previous studies (21) that showed that this concentration produced moderate, reproducible cough responses. Five other animals were exposed first to saline, then to enkephalinase in liposomes $\left(2.1 \times 10^{-6} \mathrm{M}\right.$ for $5 \mathrm{~min}$; $120 \mu \mathrm{g}$ total aerosolized dose) followed by $5 \mathrm{~min}$ of observation, and then to increasing concentrations of substance $P\left(10^{-16}-10^{-8} \mathrm{M}, 2\right.$ $\mathrm{min}$ ) followed by $8 \mathrm{~min}$ of additional observation at each dose. Next, to inhibit the effects of enkephalinase, the animals were exposed to aerosolized leucine-thiorphan $\left(10^{-5} \mathrm{M}, 5 \mathrm{~min}\right.$; SQ 28133 [32]). This concentration of leucine-thiorphan was chosen on the basis of previous studies (21) that showed that this concentration did not cause cough by itself and that it potentiated substance $P$ - and capsaicin-induced cough. Finally, these animals were exposed to aerosolized substance $P\left(10^{-16}\right.$ $\mathrm{M}, 2 \mathrm{~min}$ ), and coughs were monitored for an additional $8 \mathrm{~min}$.

In the second series of experiments, to determine whether the cough induced by capsaicin was inhibited by aerosolized recombinant enkephalinase, we exposed six other guinea pigs to aerosols of saline (2 $\mathrm{min}$ ) followed by $13 \mathrm{~min}$ of additional observation. Then we exposed them to aerosols of enkephalinase in liposomes (120 $\mu \mathrm{g}$ total aerosolized dose). After $10 \mathrm{~min}$ of additional observation, we exposed them to aerosols of capsaicin $\left(10^{-15} \mathrm{M}, 2 \mathrm{~min}\right)$ followed by $13 \mathrm{~min}$ of observation. This concentration of capsaicin was 100 times greater than the concentration required to cause a significant cough response (21). Next, to inhibit the effects of enkephalinase, the animals were exposed to aerosolized leucine-thiorphan $\left(10^{-5} \mathrm{M}, 5 \mathrm{~min}\right)$ and, finally, to capsaicin $\left(10^{-15} \mathrm{M}, 2 \mathrm{~min}\right)$ followed by $13 \mathrm{~min}$ of observation.

Because even healthy guinea pigs may have had infections by common respiratory pathogens, and because infections by Sendai virus (33) increase responsiveness to substance $P$ and decrease enkephalinase activity $(16,33)$, in the third series of experiments, we studied animals born and raised under pathogen-free conditions (Charles River Laboratories, Portage, MI). Furthermore, we dialyzed the enkephalinase in the absence of liposomes to minimize irritation. Preliminary studies were performed to determine a concentration of capsaicin that caused moderately large, reproducible responses compared with the response to the diluent for capsaicin, and on the basis of these studies, we chose a concentration of $10^{-13} \mathrm{M}$. We divided the animals into two groups of six animals each. One group received aerosolized active enkephalinase without liposomes $\left(5.9 \times 10^{-7} \mathrm{M}\right.$ for $5 \mathrm{~min} ; 33 \mu \mathrm{g}$ total aerosolized dose), and the other group received enkephalinase without liposomes that had been inactivated first by boiling for $15 \mathrm{~min}$, followed by 2 days of incubation in acidic buffer $(\mathrm{pH}=2)$ and then by dialysis against Hepes-buffered saline $(\mathrm{pH}=7.4)$. In these studies, the observer who counted coughs did not know whether an animal had received active or inactive enkephalinase. $15 \mathrm{~min}$ later, the animals were exposed to aerosolized capsaicin $\left(10^{-13} \mathrm{M}, 2 \mathrm{~min}\right)$ and were observed for an additional 13 min.

Data analysis. Data are expressed as the number of coughs (mean \pm SEM) counted in the observation periods during and after aerosol exposure. Data are compared by one-way analysis of variance and Newman-Keuls test for multiple comparisons. Significance was accepted at $P<0.05$.

Solutions. Substance $\mathrm{P}$ (Peninsula Laboratories, Belmont, CA) was dissolved in $0.1 \mathrm{~N}$ acetic acid and diluted in saline $(0.85 \% \mathrm{NaCl})$ before use. Leucine-thiorphan (a gift from Squibb Pharmaceuticals, Inc., Princeton, NJ) was dissolved in $100 \%$ ethanol, stored in the refrigerator, and diluted in saline before use. Capsaicin $\left(10^{-2} \mathrm{M}\right.$; Sigma Chemical Co., St. Louis, MO) was dissolved in 10\% Tween 80 (Sigma Chemical Co.) and $10 \%$ ethanol and was diluted in saline before use. In previous studies (21), we showed that, at the concentrations used, none of these vehicles, by itself, caused cough.

\section{Results}

In the first series of studies, substance $P$ caused significantly greater cough than saline alone did $(9.6 \pm 0.8$ vs. $2.2 \pm 0.7$ coughs/10 min; $P<0.001, n=5$ ) (Fig. 1). Recombinant 


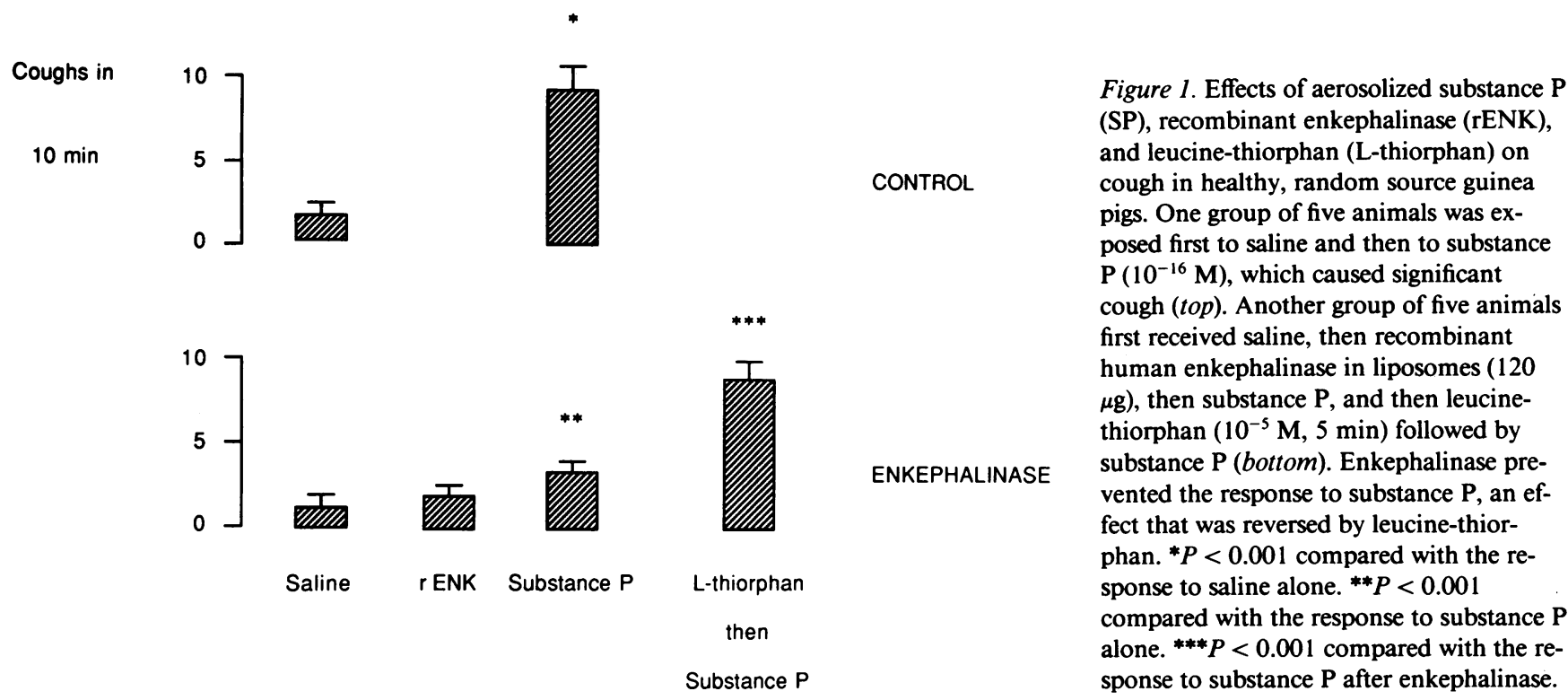

human enkephalinase in liposomes caused a slight but insignificant increase in cough compared to saline alone. However, enkepphalinase significantly inhibited the cough response to subsequent exposure to substance $\mathrm{P}\left(10^{-16} \mathrm{M} ; P<0.001, n\right.$ $=5$ ). After enkephalinase, increasing concentrations of substance $P$ did not increase cough significantly $\left(10^{-16} \mathrm{M}\right.$, $3.4 \pm 0.7 ; 10^{-14} \mathrm{M}, 4.2 \pm 0.6 ; 10^{-12} \mathrm{M}, 4.2 \pm 0.4 ; 10^{-10} \mathrm{M}$, $4.2 \pm 0.6 ; 10^{-8} \mathrm{M}, 5.4 \pm 0.6$ [ $10 \mathrm{~min}$ each $]$ ), even though the last dose of substance $P$ was delivered $\sim 2 \mathrm{~h}$ after delivering enkephalinase. However, after exposure to both enkephalinase and leucine-thiorphan, substance $P\left(10^{-16} \mathrm{M}\right)$ again increased cough significantly compared with the response to substance $\mathbf{P}$ after enkephalinase $(P<0.001, n=5)$.

In the second series of studies, enkephalinase in liposomes increased cough slightly but significantly $(P<0.05, n=6)$ (Fig. 2). However, after enkephalinase, exposure to capsaicin $\left(10^{-15}\right.$ M) did not result in a further increase in cough $(P>0.5, n$ $=6$ ). Subsequent exposure to leucine-thiorphan followed by capsaicin resulted in significantly increased cough compared

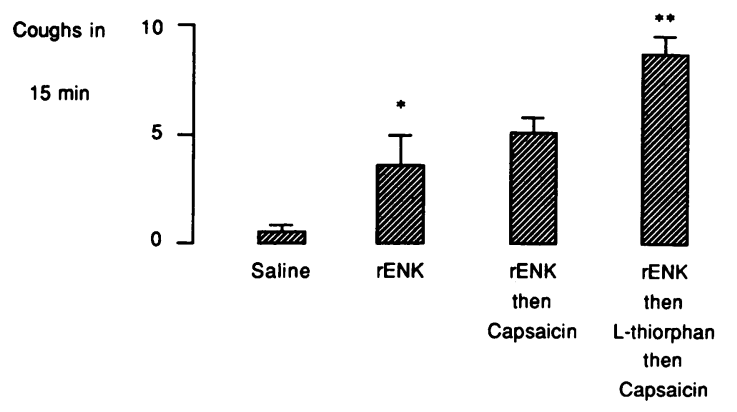

Figure 2. Effects of recombinant enkephalinase (rENK), capsaicin, and leucine-thiorphan (L-thiorphan) on cough in six healthy, random-source guinea pigs. Animals were exposed first to saline and then to recombinant enkephalinase in liposomes $(120 \mu \mathrm{g})$, which increased cough slightly and significantly. After enkephalinase, capsaicin $\left(10^{-15} \mathrm{M}, 2 \mathrm{~min}\right)$ did not increase cough, but after further exposure to leucine-thiorphan $\left(10^{-5} \mathrm{M}, 5 \mathrm{~min}\right)$, capsaicin increased cough significantly. ${ }^{*} P<0.05$ compared with the response to saline alone. ${ }^{* *} P<0.025$ compared with the response to capsaicin after enkephalinase. with the response to capsaicin after enkephalinase $(P<0.025$, $n=6)$.

In the third study, we used pathogen-free guinea pigs. After exposing them to Hepes-buffered saline $(5 \mathrm{~min})$, the diluent for capsaicin $\left(10^{-10} \%\right.$ Tween $80,10^{-10} \%$ ethanol; equivalent to that present in $10^{-13} \mathrm{M}$ capsaicin) alone produced few coughs ( $n=5$ animals) (Fig. 3), but capsaicin $\left(10^{-13} \mathrm{M}\right)$ produced significant cough $(P<0.05, n=5)$. Neither active recombinant enkephalinase (dialyzed in the absence of liposomes) nor inactive recombinant enkephalinase alone caused cough

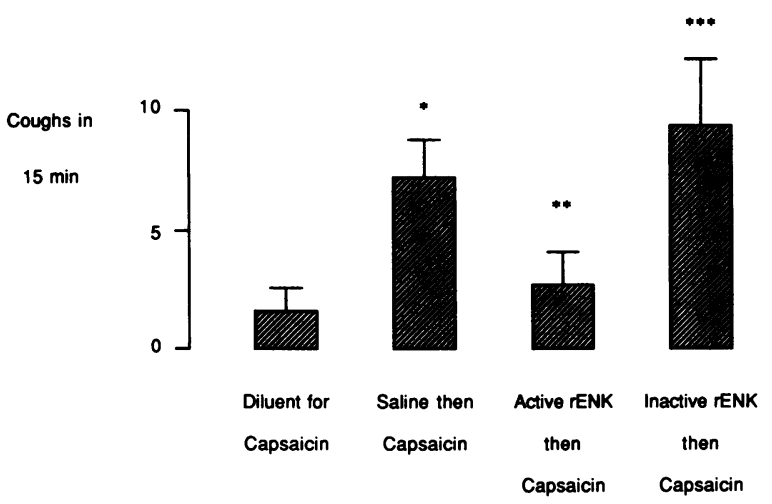

Figure 3. Effects of capsaicin, recombinant enkephalinase dialyzed in the absence of liposomes ( $\mathrm{rENK}$ ), and inactivated enkephalinase in pathogen-free guinea pigs. One group of five animals was exposed to Hepes-buffered saline followed by the diluent for capsaicin $\left(10^{-10} \%\right.$ Tween $80,10^{-10} \%$ ethanol in saline), which did not cause significant cough. Another group of animals was exposed to Hepes-buffered saline followed by capsaicin $\left(10^{-13} \mathrm{M}\right)$, which caused significant coughing (two left columns). In a blinded study in which the observer did not know whether the animal had received active or inactive enkephalinase, six other animals in each group received aerosols of either active or inactive enkephalinase ( $33 \mu \mathrm{g}, 5 \mathrm{~min}$ ) followed by capsaicin $\left(10^{-13} \mathrm{M}\right)$. Active enkephalinase prevented the response to capsaicin, but inactive enkephalinase did not significantly decrease the response to capsaicin (two right columns). ${ }^{*} P<0.05$ compared with the response to the diluent for capsaicin alone. ${ }^{* *} P<0.05$ compared with the response to capsaicin alone. ${ }^{* * *} P<0.05$ compared with the response to capsaicin after active enkephalinase. 
$(0.7 \pm 0.5 / 15 \mathrm{~min}$ and $1.5 \pm 1.0 / 15 \mathrm{~min}$, respectively; $P>0.3, n$ $=6$ each). Active enkephalinase pretreatment prevented the increase in cough in response to capsaicin $(P>0.5$ compared with the response to saline, and $P<0.05$ compared with the response to capsaicin alone; $n=6$ ), whereas after inactivated enkephalinase, the frequency of the capsaicin-induced cough was similar to that produced by capsaicin alone (second column from the left, $P>0.3, n=6$ ).

\section{Discussion}

These studies show that recombinant human enkephalinase prevents cough in guinea pigs induced by substance $P$ or by capsaicin. This conclusion is based on studies in both healthy, random-source guinea pigs and in pathogen-free guinea pigs. We also conclude that two preparations of enkephalinase are effective, one in which the enzyme is incorporated into liposomes, and the other in which the enkephalinase is dialyzed in the absence of liposomes to remove free detergent. These results also suggest that the endogenous neuropeptide responsible for mediating cough responses to capsaicin is accessible to aerosols of enkephalinase inhaled into the airways. Because the aerosol particles are relatively large $(7.6 \mu \mathrm{m})$, they are deposited primarily in the large airways, the sites of cough receptors (3), and, thus, would be in an ideal position to modulate the effects of cough-producing stimuli. Because enkephalinase is a large molecule $(94,000 \mathrm{D})$ and is very hydrophobic, we believe that it does not penetrate very far into the airway interstitium. This suggests that the sites of release of the endogenous peptides responsible for mediating capsaicin-induced cough are near the airway surface.

The inhibitory effect of recombinant enkephalinase was not due to nonspecific effects of the enzyme preparations because after exposure to the enkephalinase inhibitor, cough was increased in response to both substance $P$ and to capsaicin. Additionally, the inactivated enzyme, which contains similar chemical components as the active enzyme, did not inhibit cough induced by capsaicin. Thus, we conclude that the inhibitory effect of recombinant enkephalinase was due to its enzymatic properties.

Some of the random-source guinea pigs coughed after exposure to the liposome preparation of enkephalinase, but the effect was not very large and was significant in only one of the studies. It is likely that the cough observed in these animals was due to the lipids contained in the liposomes. Alternatively, it is possible that the pathogen-free guinea pigs used for this part of the study were less sensitive to inhaled materials because they required $\sim 100$ times more capsaicin than did the random-source animals. However, the differences between the two groups of guinea pigs could not account for the effects, because enkephalinase inhibited cough significantly in both groups.

The amount of recombinant enkephalinase reaching the receptors that mediate cough is difficult to estimate. Although 120 and $33 \mu \mathrm{g}$ were delivered in $5 \mathrm{~min}$ to the two groups respectively, only a small fraction of the aerosolized dose was inhaled by the animal. Furthermore, some of the inhaled aerosol was probably deposited in the nose, a site from which cough responses cannot be elicited. It is also likely that some of the deposited enkephalinase was cleared from the nose and trachea and was swallowed. Thus, the amount of exogenous enkephalinase reaching the airways and therefore responsible for inhibiting the cough response was much lower than the doses delivered by the generator. Because the cough response is very sensitive to inhaled substance $P$ and capsaicin (concentration range, $10^{-13}-10^{-16} \mathrm{M}$ ), it is reasonable to conclude that only low doses of aerosolized enzyme are needed to significantly inhibit cough induced by these irritants.

Although we did not determine the maximum duration of action of aerosolized enkephalinase, a single exposure to enkephalinase inhibited cough induced by $10^{-8} \mathrm{M}$ substance $P$ delivered $\sim 2 \mathrm{~h}$ after the enkephalinase. That subsequent exposure to leucine-thiorphan reversed the effect of enkephalinase suggests that, at this time, the enzyme had been active.

The exact mechanisms causing cough in disease are unknown, and the role of neural inflammation in disease is also unclear. Although the identity of the peptide responsible for mediating cough is not certain, several studies suggest that the release of tachykinins from sensory nerves can mediate cough. Various mechanical (3), chemical $(22,23,34)$, and pharmacological (35) stimuli can activate vagal sensory neurons that may result in the release of tachykinins (12). In the spinal cord, capsaicin has been shown to release immunoreactive substance $P(22)$, and chronic treatment depletes tachykinins from sensory nerves $(23,34)$. Furthermore, in the airways, tachykinin receptor antagonists prevent the effects of capsaicin or of electrical field stimulation (11), thereby inhibiting both smooth muscle contraction (11) and increases in vascular permeability (12). The mechanisms that mediate substance P-induced cough are not known, but there are several possibilities. Substance $P$ most likely acts by stimulating sensory nerves, as it can in cats (36), although it can also release histamine from mast cells (37). However, the concentrations of substance $P$ that are required to release histamine are much higher than those necessary to stimulate cough. Similarly, although mechanical stimulation of cough receptors may occur secondarily to substance P-mediated mucus secretion $(9,38)$ or bronchoconstriction $(11,24)$, the concentrations necessary to stimulate these responses are higher than those necessary to stimulate cough.

The high sensitivity of the cough response in guinea pigs is similar to the sensitivities of behavioral and electrophysiological responses to pheromones in insects, in which only a few molecules are necessary to elicit responses $(39,40)$. Many biochemical agents can induce cough responses. In addition to histamine (41), methacholine (35), prostaglandins $E_{1}, E_{2}, F_{2 \alpha}$ (42), prostaglandin $D_{2}(43)$, and bradykinin (44), also can stimulate cough. Histamine, prostaglandins $E_{2}$ and $F_{2 \alpha}$, and bradykinin may stimulate cough by their abilities to stimulate bronchial $C$ fibers $(5,45,46)$. Because substance $P$ is effective in stimulating cough at concentrations $\left(10^{-17}-10^{-16} \mathrm{M}\right)$ well below those of histamine $\left(10^{-8}-10^{-7} \mathrm{M}\right)$, substance $P$ appears to be one of the most potent stimuli to cough known. Because cigarette smoke probably releases substance $P$ from sensory nerves (47) in the airways, this is a possible mechanism by which smoke causes cough (48). Furthermore, because nonsmokers cough in response to cigarette smoking nearby (48), the cough response in humans is very sensitive to irritants.

The effectiveness of recombinant enkephalinase in inhibiting substance $P$-induced cough is suggested by the high affinity and turnover numbers of substance $P$ by enkephalinase. Sub- 
stance $\mathbf{P}$ and other tachykinins are among the best naturally occurring substrates for enkephalinase $(49,50)$. The findings that enkephalinase inhibitors potentiate substance P- and capsaicin-induced cough (21) and that enkephalinase inhibits capsaicin-induced cough further support the conclusion that the peptide released by capsaicin that mediates cough is a good substrate for enkephalinase. These studies also suggest that capsaicin releases peptides near the sites of deposition of the aerosolized enzyme. Because some of the same stimuli that release tachykinins also produce cough $(25,26)$, it is reasonable that at least some cough is due to this neural mechanism. Other stimuli that cause cough such as exposure to cigarette smoke (48) or distilled water (51) may also act via the release of neuropeptides. By studying the effects of enkephalinase in these clinical conditions, this hypothesis can be tested.

Because decreases in tracheal enkephalinase possibly account for the hyperresponsiveness to substance $P$ induced by toluene diisocyanate (27), mycoplasmal infections (16), or viral infections (33), it is possible that therapy using recombinant enkephalinase may be useful in treating diseases in which there is an inadequate amount of enkephalinase present. Enkephalinase is found in many organs and tissues including kidney (52), brain (53), and gastrointestinal tract (54), and decreases in enkephalinase at these locations may lead to disease. Enkephalinase might also be useful in treating diseases in which large amounts of peptides are released by chronic stimulation of sensory nerves or bỳ overproduction of peptides by other cells. Thus, enkephalinase might treat cough or bronchial narrowing associated with airway diseases such as asthma, chronic bronchitis, and cystic fibrosis.

Recombinant enkephalinase might also be useful in treating diseases of tissues that normally contain no endogenous enzyme. Furthermore, enkephalinase cleaves a large number of different peptides including tachykinins, kinins, neurotensin, cholecystokinin, bombesin, and others, so enkephalinase might be useful in treating any diseases that are the result of actions of these peptides. Because many organs and tissues contain peptides that are cleaved by enkephalinase, therapeutic application of this enzyme may be useful in treating diseases of many different organ systems.

\section{Acknowledgments}

The authors wish to thank Paul Graf for his technical assistance and Beth Cost and Patty Snell for manuscript preparation.

This work was supported in part by National Institutes of Health (NIH) Program Project grant HL-24136. Dr. Borson is the recipient of NIH First Independent Research Service and Transition Award HL-38947.

\section{References}

1. Widdicombe, J. G. 1977. Some experimental models of acute asthma. J. R. Coll. Phys. Lond. 11:141-155.

2. Banner, A. S. 1986. Cough: physiology, evaluation, and treatment. Lung. 164:79-92.

3. Widdicombe, J. G. 1954. Respiratory reflexes from the trachea and bronchi of the cat. J. Physiol. (Lond.). 123:55-70.

4. Nadel, J. A., and J. G. Widdicombe. 1963. Reflex control of airway size. Ann. NY Acad. Sci. 109:712-722.

5. Coleridge, H. M., and J. C. G. Coleridge. 1977. Impulse activity in afferent vagal C-fibers with endings in the intrapulmonary airway of dogs. Respir. Physiol. 29:125-142.
6. Ghatei, M. A., N. Sheppard, D. J. O'Shaughnessy, T. E. Adrian, G. P. McGregor, J. M. Polak, and S. R. Bloom. 1982. Regulatory peptides in the mammalian respiratory tract. Endocrinology. 111:1248-1254.

7. Lundberg, J. M., T. Hokfelt, C.-R. Martling, A. Saria, and S. Cuello. 1984. Substance P-immunoreactive sensory nerves in the lower respiratory tract of various animals including man. Cell Tissue Res. 235:251-261.

8. Baker, A. P., L. M. Hillegass, D. A. Holden, and W. J. Smith. 1977. Effect of kallidin, substance $P$, and other basic polypeptides on the production of respiratory macromolecules. Am. Rev. Respir. Dis. 115:811-817.

9. Borson, D. B., R. Corrales, S. Varsano, M. Gold, N. Viro, G. Caughey, J. Ramachandran, and J. A. Nadel. 1987. Enkephalinase inhibitors potentiate substance P-induced secretion of ${ }^{35} \mathrm{SO}_{4}$-macromolecules from ferret trachea. Exp. Lung Res. 12:21-36.

10. Nilsson, G., E. Dahlberg, E. Brodin, F. Sundler, and K. Strandberg. 1977. Distribution and constrictor effect of substance $P$ in guinea pig tracheobronchial tissue. In Substance P. Raven Press, New York. 75-81.

11. Sekizawa, K., J. Tamaoki, J. A. Nadel, and D. B. Borson. 1987. Enkephalinase inhibitor potentiates substance P- and electrically induced contraction in ferret trachea. J. Appl. Physiol. 63:1401-1405.

12. Lundberg, J. M., A. Saria, E. Brodin, S. Rosell, and K. Folkers. 1983. A substance $P$ antagonist inhibits vagally induced increase in vascular permeability and bronchial smooth muscle contraction in the guinea pig. Proc. Natl. Acad. Sci. USA. 80:1120-1124.

13. McDonald, D. M. 1988. Neurogenic inflammation in the rat trachea. I. Changes in venules, leucocytes, and epithelial cells. J. Neurocytol. 17:583-603.

14. Tanaka, D. T., and M. M. Grunstein. 1984. Mechanisms of substance P-induced contraction of rabbit airway smooth muscle. $J$. Appl. Physiol. 57:1551-1557.

15. Sekizawa, K., J. Tamaoki, P. D. Graf, C. B. Basbaum, D. B. Borson, and J. A. Nadel. 1987. Enkephalinase inhibitor potentiates mammalian tachykinin-induced contraction in ferret trachea. J. Pharmacol. Exp. Ther. 243:1211-1217.

16. Borson, D. B., J. J. Brokaw, K. Sekizawa, D. M. McDonald, and J. A. Nadel. 1989. Neutral endopeptidase and neurogenic inflammation in rats with respiratory infections. J. Appl. Physiol. 66:26532658.

17. Iwamoto, I., I. F. Ueki, D. B. Borson, and J. A. Nadel. 1989. Neutral endopeptidase modulates tachykinin-induced increase in vascular permeability in guinea pig skin. Int. Arch. Allergy Appl. Immunol. 88:288-293.

18. Umeno, E., J. A. Nadel, H.-T. Huang, and D. M. McDonald. 1989. Inhibition of neutral endopeptidase potentiates neurogenic inflammation in the rat trachea. J. Appl. Physiol. 66:2647-2652.

19. Umeno, E., D. M. McDonald, and J. A. Nadel. 1989. Fate of neutrophils that adhere to venules in neurogenic inflammation of the rat trachea and role of neutral endopeptidase: migration or detachment Am. Rev. Respir. Dis. 139:A236. (Abstr.)

20. Borson, D. B., B. Malfroy, M. Gold, J. Ramachandran, and J. A. Nadel. 1986. Tachykinins inhibit enkephalinase activity from tracheas and lungs of ferrets Physiologist. (Abstr.) 29:174.

21. Kohrogi, H., P. D. Graf, K. Sekizawa, D. B. Borson, and J. A. Nadel. 1988. Neutral endopeptidase inhibitors potentiate substance $P$ and capsaicin-induced cough in awake guinea pigs. J. Clin. Invest. 82:2063-2068.

22. Gamse, R., A. Molnar, and F. Lembeck. 1979. Substance $P$ release from spinal cord slices by capsaicin. Life Sci. 25:629-636.

23. Lundberg, J. M., and A. Saria. 1982. Bronchial smooth muscle contraction induced by stimulation of capsaicin-sensitive sensory neurons. Acta. Physiol. Scand. 116:473-476.

24. Lundberg, J. M., C. R. Martling, and A. Saria. 1983. Substance $\mathrm{P}$ and capsaicin-induced contraction of human bronchi. Acta Physiol. Scand. 119:49-53. 
25. Collier, J. G., and R. W. Fuller. 1984. Capsaicin inhalation in man and the effects of sodium cromoglycate. Br. J. Pharmacol. 81:113-117.

26. Forsberg, K., and J.-A. Karlsson. 1986. Cough induced by stimulation of capsaicin-sensitive sensory neurons in conscious guinea-pigs. Acta. Physiol. Scand. 128:319-320.

27. Sheppard, D., J. E. Thompson, L. Scypinski, D. Dusser, J. A. Nadel, and D. B. Borson. 1988. Toluene diisocyanate increases airway responsiveness to substance $P$ and decreases airway enkephalinase. $J$. Clin. Invest. 81:1111-1115.

28. Malfroy, B., W.-J. Kuang, P. H. Seeburg, A. J. Mason, and P. R. Schofield. 1988. Molecular cloning and amino acid sequence of human enkephalinase (neutral endopeptidase). FEBS (Fed. Eur. Biochem. Soc.) Lett. 229:206-210.

29. Graham, F. L., J. Smiley, W. C. Russel, and R. Nairin. 1977. Characteristics of a human cell line transformed by DNA from human adenovirus type 5. J. Gen. Virol. 36:59-77.

30. Gorman, C. M., D. Gles, P. R. Schofield, H. Kado-Fong, and B. Malfroy. 1989. Expression of enzymatically active enkephalinase (neutral endopeptidase) in mammalian cells. J. Cell. Biochem. 39:277-284.

31. Llorens, C. B., B. Malfroy, J. C. Schwartz, G. Gacel, B. P. Roques, J. Roy, J. L. Morgat, F. Javoy-Agid, and Y. Agid. 1982. Enkephalin dipeptidyl carboxypeptidase (enkephalinase) activity: selective radioassay, properties, and regional distribution in human brain. J. Neurochem. 39:1081-1089.

32. Gordon, E. M., D. W. Cushman, R. Tung, H. S. Cheung, F. L. Wang, and N. G. Delaney. 1983. Rat brain enkephalinase: characterization of the active site using mercaptopropanoyl amino acid inhibitors, and comparison with angiotensin converting enzyme. Life Sci. 33(Suppl. 1):113-116.

33. Jacoby, D. B., J. Tamaoki, D. B. Borson, and J. A. Nadel. 1988. Influenza infection increases airway smooth muscle responsiveness to substance $\mathrm{P}$ in ferrets by decreasing enkephalinase. J. Appl. Physiol. 64:2653-2658.

34. Jancso, G., E. Kiraly, and A. Jancso-Gabor. 1977. Pharmacologically induced selective degeneration of chemosensitive primary sensory neurons. Nature (Lond.). 270:741-743.

35. Chausow, A. M., and A. S. Banner. 1983. Comparison of the tussive effects of histamine and methacholine in humans. J. Appl. Physiol. 55:541-546.

36. Lew, W. Y. W., and J. C. Longhurst. 1986. Substance P, 5-hydroxytryptamine, and bradykinin stimulate abdominal visceral afferents. Am. J. Physiol. 250:R465-R473.

37. Foreman, J. C., C. C. Jordan, P. Oehme, and H. Renner. 1983. Structure-activity relationships for some substance P-related peptides that cause wheal and flare reactions in human skin. J. Physiol. (Lond.). 335:449-465.

38. Gashi, A. A., D. B. Borson, W. E. Finkbeiner, J. A. Nadel, and C. B. Basbaum. 1986. Neuropeptides degranulate serous cells of ferret tracheal glands. Am. J. Physiol. 251(Cell Physiol. 20):C223-C229.
39. Kaissling, K.-E. 1971. Insect olfaction. In Handbook of Sensory Physiology. Springer Verlag, Berlin. 351-431.

40. Boeckh, J., and V. Boeckh. 1979. Threshold and odor specificity of pheromone-sensitive neurons in the deuterocerebrum of Antheraea pernyi and A. polyphemus (Saturnidae). J. Comp. Physiol. 132: 235-242.

41. Simonsson, B. G., F. M. Jacobs, and J. A. Nadel. 1967. Role of autonomic nervous system and the cough reflex in the increased responsiveness of airways in patients with obstructive airway disease. $J$. Clin. Invest. 46:1812-1818.

42. Smith, A. P., M. F. Cuthbert, and L. S. Dunlop. 1975. Effects of inhaled prostaglandins $E_{1}, E_{2}$ and $F_{2 \alpha}$ on the airway resistance of healthy and asthmatic man. Clin. Sci. Mol. Med. 48:421-430.

43. Fuller, R. W., C. M. S. Dixon, C. T. Dollery, and P. J. Barnes. 1986. Prostaglandin $D_{2}$ potentiates airway responsiveness to histamine and methacholine. Am. Rev. Respir. Dis. 133:252-254.

44. Fuller, R. W., C. M. S. Dixon, F. M. C. Cuss, and P. J. Barnes. 1987. Bradykinin-induced bronchoconstriction in humans: mode of action. Am. Rev. Respir. Dis. 135:176-180.

45. Coleridge, H. M., J. C. G. Coleridge, K. H. Ginzel, D. G. Baker, R. B. Banzett, and M. A. Morrison. 1976. Stimulation of irritant receptors and afferent $\mathrm{C}$-fibers in the lungs by prostaglandins. Nature (Lond.). 264:451-453.

46. Kaufman, M. P., H. M. Coleridge, J. C. G. Coleridge, and D. G. Baker. 1980. Bradykinin stimulates afferent vagal C-fibres with chemosensitive endings in the heart and aorta of the dog. J. Appl. Physiol. 48:511-517.

47. Lundberg, J. M., C.-R. Martling, A. Saria, K. Folkers, and S. Rosell. 1983. Cigarette smoke-induced airway oedema due to activation of capsaicin-sensitive vagal afferents and substance $P$ release. Neuroscience. 10:1361-1368.

48. Loudon, R. G. 1976. Smoking and cough frequency. Am. Rev Respir. Dis. 114:1033-1036.

49. Matsas, R., A. J. Kenny, and A. J. Turner. 1984. The metabolism of neuropeptides: the hydrolysis of peptides, including enkephalins, tachykinins and their analogues, by endopeptidase-24.11. Biochem. J. 223:433-440.

50. Skidgel, R. A., A. Engelbrecht, A. R. Johnson, and E. G. Erdos. 1984. Hydrolysis of substance $P$ and neurotensin by converting enzyme and neutral endoproteinase. Peptides (NY). 5:769-776.

51. Sheppard, D., N. Rizk, H. A. Boushey, and R. A. Bethel. 1983. Mechanism of cough and bronchoconstriction induced by distilled water aerosol. Am. Rev. Respir. Dis. 127:691-694.

52. Kerr, M. A., and A. J. Kenny. 1974. The purification and specificity of a neutral endopeptidase from rabbit kidney brush border. Biochem. J. 137:477-488.

53. Malfroy, B., J. P. Swerts, A. Guyon, B. P. Roques, and J. C. Schwartz. 1978. High-affinity enkephalin-degrading peptidase in brain is increased after morphine. Nature (Lond.). 276:523-526.

54. Power, D. M., N. Bunnett, A. J. Turner, and R. Dimaline. 1987. Degradation of endogenous heptadecapeptide gastrin by endopeptidase 24.11 in the pig. Am. J. Physiol. 253:G33-G39. 